\title{
Part I: Main Lectures Hauptvorträge Rapports principaux
}

Proceedings of the VIth International Congress of Psychotherapy

Verhandlungen des vi. internationalen Psychotherapiekongresses

Comptes rendus du vie Congrès international de Psychothérapie

London 24-29 August 1964

Edited by - herausgegeben von - rédigé par

Malcolm Pines, Richmond, Surrey Theodor Spoerri, Waldau, Bern

BASEL (Switzerland) S. KARGER NEW YORK

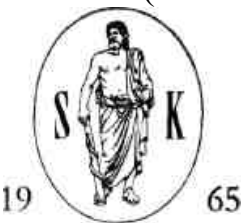

The Proceedings of the previous International Congresses of Psychotherapy have been published as follows:

First Congress London 1949

Second Congress Leiden 1951

Third Congress Zurich 1954

Main Lectures, Papers of Sub-Sections, Communications. With 92 contributions. Parts $1+2$. XII

+742 p., sFr. 84.-(S. Karger, Basel/New York 1955)

Fourth Congress Barcelona 1958

Selected Lectures

Topical Problems of Psychotherapy, Vol. 3

VIII+ 292 p., 21 fig., sFr. 54.-(S.Karger, Basel/New York 1960)

Fifth Congress Vienna 1961

Part I Main Lectures

Acta Psychotherapeutica et Psychosomatica, Vol. 10, No. $2+3$

176 p., 4 pel., 4 tab., sFr. 31.50

Part II Selected Lectures

Topical Problems of Psychotherapy, Vol. 4

VI+ 274 p., 10 fig., 4 tab., sFr. 63.-

Part III Psychosomatic Medicine in Practice

Advances in Psychosomatic Medicine, Vol.3

VI + 207p.,17fig.,5tab., sFr.52.-

Part IV Psychotherapy and Psychoses

Bibliotheca Psychiatrica et Neurologica, Fasc. 118

VI+ 94 p., 3 tab., sFr. 19.-

Part V Progress in Child Psychiatry

VI + 72p., sFr. 17.-

(S. Karger, Basel/New York 1963) Sixth Congress London 1964 
Part I Main Lectures

Psychotherapy and Psychosomatics, Vol. 13, No. 1-3 (1965)

XII +248 p., 4 fig., 3 tab., sFr. 34.80

Part II Psychotherapy of Adolescents

Psychotherapy and Psychosomatics, Vol. 13, No. 4 (1965)

VIII+72 p., 1 fig., 1 tab., sFr. 14.20

Part III Psychiatric Family Studies

Confinia Psvchiatrica, Vol. 8, No. 1 (1965)

VIII+56 p., sFr. 14.20

Part IV Selected Lectures

VIII+160 p., 10 fig., 12 tab., sFr. 28.40

(S. Karger, Basel/New York 1965)

Verlag S.Karger AG,Arnold-Böcklin-Strasse 25, Basel (Switzerland)

All rights, including that of translation into foreign languages, reserved.

Photomechanic reproduction (photocopy, microcopy) of this book or part of

it without special permission of the publishers is prohibited.

(C)

Copyright 1965 by S. Karger AG, Basel

Printed in Switzerland by Buchdruckerei Brín+Tanner AG, Basel

Cliches: Steiner \& Cie. AG, Basel

General Index of the Proceedings

Gesamtübersicht über den Kongressbericht

Table des matières générale des comptes rendus

Part I Main Lectures - Hauptvorträge - Rapports principaux

Psychotherapy and Psychosomatics, Vol. 13, No. 1-3 (1965)

List of Authors -Liste der Autoren - Liste des auteurs

VIII

Pines, M. (Richmond, Surrey): Introduction

IX

Boss, M. (Zurich): Presidential Address at the Opening Session

Main, T. F. (Richmond, Surrey): The Search for Sense

Anthony, E.J. (St. Louis, Miss.): Developments in Child Psychotherapy.

Varieties and Vicissitudes of the Therapeutic Situation in the Treat

ment of Children

15

Fordham, M. (London): The Self in Childhood 29

Freud, Anna (London): Some Recent Developments in Child-Analysis .. 36 Dührssen,

Annemarie (Berlin): Wissenschaftliche und medizinalpolitische

Aspekte in der Kinderpsychiatrie 47

Laing, R.D. (London): Practice and Theory - The Present Situation .... 58

Ruesch, J. (San Francisco, Calif.): Psychotherapy for the Well and Psycho

therapy for the Ill 68

Boss, M. (Zurich): Discussion of the Paper by J. Ruesch 82

Benedetti, G. (Basel): Die Handhabung der Regression in der individuellen

Psychotherapie schizophrener Psychosen 87

Zetzel, Elizabeth R. (Cambridge, Mass.): The Use and Misuse of Psychoanalysis in Psychiatric Evaluation and Psycho therapeutic Practice ... 101 Sutherland, J.D. (London): Recent Advances in the Understanding of

Small Groups, their Disorders and Treatment 
Stock Whitaker, Dorothy (Leeds): The Processes by which Change Occurs and the Role of Insight 126

Schwartz, E. K. (New York, N.Y.): Group Psychotherapy: The Individual and the Group 142

Foulkes, S.H. (London): Group Psychotherapy: The Group-analytic View.

A Contribution to the Discussion 150

Knobloch, F. (Prague): Family Psychotherapy 155

Stanton, A.H. (Belmont, Mass.): Some Therapeutic Mechanisms Arising

from Psychiatric Hospital Social Structure 164

Cumming, J. and Cumming, Elaine (Syracuse, N.Y.): The Value Problem

in Psychiatry 186

Menzies, Isabel E.P. (London): Some Mutual Interactions between Orga

nisations and their Members 194

Weddell, Doreen (Richmond, Surrey): Change as a Learning Situation .. 201 Mertens de

Wilmars, Ch. (Louvain): L'intervention sur les organisations 206 Trist, E. L. (London): The

Need of the Social Psychiatrist to Influence Wider

Social Networks and their Environments 229

Clark, D.H. (Cambridge): The Developing Concept of the Therapeutic

Community 238

Boss, M. (Zurich): Presidential Address at the Closing Session 246

VI General Index - Gesamtübersicht - Table des matières générale

Part II Psychotherapy of Adolescents

Psychotherapy and Psychosomatics, Vol. 13, No. 4 (1965)*

Attardo, Nettie (New York, N.Y.): Psychodynamic Factors in the

Mother-Child Relationship in Adolescent Drug Addiction: A Compari

son of Mothers of Schizophrenics and Mothers of Normal Adolescent

Sons (249) 1

Edwards, F.H. (Richmond, Surrey): Aetiological Patterns in Delinquent

Adolescents. A Survey of 66 Cases Seen at the Portman Clinic

1961-1964 (256) 8

Evans, J. (Richmond, Surrey): In-Patient Analytic Group Therapy of

Neurotic and Delinquent Adolescents; Some Specific Problems Asso

ciated with these Groups (265) 17

Hoppe, K.D. (Beverly Hills, Calif.); Molnar, J. and Newell, J.E. (Los

Angeles, Calif.): Love- and Hate-Addiction in Delinquent Male Ado

lescents (271) 23

Hoxter, Shirley (London): The Experience of Puberty and Some Implica

tions for Psychotherapy $\quad$ (278) 30

Langen, D. (Tubingen): The Psychotherapy of Puberal Crises from the

Point of View of their Subsequent Development $\quad$ (285) 37

Laufer, M. (London): A Psychoanalytical Approach to Work with Ado

lescents. The Work of the Young People's Consultation Centre (Lon

don) with Remarks on Diagnosis and Technique (292) 44

Marshall, Margaret A. (Lincoln Park, N.J.) and Weinberg, Lilian

(West Caldwell, N.J.): Implementing an Adolescent Service in an

Ongoing Mental Hospital (299) 51 
Martin, Doreen (Richmond, Surrey): The Beginnings of the Growth and Development of an Adolescent Unit in the Cassel Hospital .. (309) 61

Zeise, W.J. and Elsaesser, Erika (Munich): Individual Observations

During Psychoanalytic Group Therapy with Adolescents .... (314) 66

Part III Psychiatric Family Studies

Confinia Psychiatrica, Vol. 8, No. 1 (1965)

Alanen, Y.O.; Rekola, J.K.; Stewen, Anneli; Takala, K. and Tuo-

vinen, M. (Helsinki): On Factors Influencing the Onset of Schizo

phrenia in the Light of a Family Study

1

Elles, Gillian W. (London): Family Treatment from a Therapeutic Com

munity 9

Ferreira, A. J. (San José, Calif.): Family Myths: The Covert Rules of the

Relationship 15

Finger, Sally (Staten Island, N.Y.): Concurrent Group Therapy with

Adolescent Unmarried Mothers and their Parents 21

* The figures in brackets refer to the journal page numbers. General Index - Gesamtübersicht -

Table des Matières générale VII

Fleck, S. (New Haven, Conn.): Some General and Specific Indications for

Family Therapy 27

Satir, Virginia M. (Palo Alto, Calif.): The Family as a Treatment Unit 37

Scott, R.D. (St. Albans, Herts): Perspectives on the American Family

Studies in Schizophrenia 43

Zuк, G.H. (Philadelphia, Pa.): On Silence and Babbling in Family Psycho

therapy with Schizophrenics 49

Part IV Selected Lectures

Published in a separate volume

Blair, Margaret (Wembley, Middlesex) and Pasmore, Jean (London):

Frigid Wives 1

Campos Avillar, J. (Barcelona): Joint Treatment of Schizophrenic Children

and their Mothers in a Group 8

Cowan, L.H. (Glasgow): Psychotherapy and Persistent Pain 14

Ferchland, Editha (Umkirch, Freiburg i. Br.): Methodological Problems

of Group Diagnosis in the In-patient Psychotherapy of the Psychoso

matic Clinic 27

Fierz, H. K. (Zurich): The Training of a Specialist in Psychotherapy .... 39

Gallwey, P.L.G. (London): Prison Structure and Criminal Aggression 44

Kayser, H. (Zurich): A Therapeutic Community with Chronic Schizo

phrenics 52

Knobel, M. and Ucha Udabe, R. (Buenos Aires): A Psychodynamic Com ponent of Medication 60

Ledermann, E. K. (London): Existential Psychotherapy and the Principles of Scientific Medicine 68

Lindemann, E. (Boston, Mass.): The Timing of Psychotherapy 75

McPherson,F.M. and Walton, H.J. (Edinburgh): Changes in Communi cations of Patients Treated in a Closed Therapeutic Group 91

Palazzoli Selvini, Mara (Milano): The Meaning of the Body for Anorexic 
Patients $\quad 98$

Piers, G. and Piers, Maria W. (Chicago, Ill.): Modes of Learning and the Analytic Process 104

Rojas Bermudez, J.; Martinez, C. and Pavlovsky, E. (Buenos Aires):

Evaluation of the Different Psychotherapeutic Techniques especially

with Group Psychotherapy and Psychodrama Performed throughout

Eight Years of Labour on Children and Adolescents Ill

Shlien, J.M. (Chicago, Ill.): Cross-Theoretical Criteria in Time-Limited

Therapy 118

Sifneos, E. (Boston, Mass.): Seven-Years' Experience with Short-Term

Dynamic Psychotherapy 127

Skynner, A. C. R. (London): Group Analytic Themes in Training- and Case-

Discussion Groups 136

Tischler, S. (St. Albans, Herts): Observations Based on Psychotherapy with

the Parents of Psychotic Children 143

Ziferstein, I. (Los Angeles, Calif.): Direct Observations of Psychotherapy

in the USSR 150

List of Authors - Liste der Autoren - Liste des auteurs

Alanen,Y.O., M.D.,Lapinlahti Hosptal, Helsinki (Finland)

Anthony, E. J., Prof., M.D., 369 North Taylor Ave.,

St. Louis 8, Mo. (USA)

Attardo, N., Ph. D., 77 Park Avenue, New York 16,

N.Y. (USA)

Benedetti, G., Prof. Dr., Psychiatrische Universitäts-

Poliklinik, Petersgraben 1, 4000 Basel (Schweiz)

Blair, M.J., M.B.B. S., 2 Forty Lane, Wembley,

Middlesex (England)

Boss, M., Prof. Dr., Bahnhofstrasse 53, 8702 Zollikon

(Schweiz)

Campos Avillar, J., M.D., Paseo de San Gervasio 30,

Atico, Barcelona 6 (Spain)

Clark, D.H., F.R.C.P.E., D.P.M., Fulbourn Hospital,

Cambridge (England)

Cowan, L.H., M.B., Ch. B·, Landsdowne Clinic for

Functional and Nervous Disorders, 4 Royal Crescent,

Glasgow C.3 (Scotland)

Cumming, E., Ph.D., State of New York Department

of Mental Hygiene, Mental Health Research Unit,

Rm. 518, State Office Bldg., 333 East Washington Street,

Syracuse, N.Y.13202 (USA)

Cumming, J., M.D., State of New York Department

of Mental Hygiene, Mental Health Research Unit,

Rm. 518, State Office Bldg., 333 East Washington Street,

Syracuse, N.Y. 13202 (USA)

Dührssen, A., Prof. Dr. med., Barstrasse 24a, 1 Berlin 31

(Deutschland) 
Edwards, F.H., M.D., Oak Lodge, Ham Common, Richmond, Surrey (England)

Elles, G.W., 23 Holland Park, London W.1l (England)

Evans, J., M.D., The Cassel Hospital, Ham Common,

Richmond, Surrey (England)

Ferchland, E., Dipl.-Psych., Landhaus, Umkírch

bei Freiburg i.Br. (Deutschland)

Ferreira, A.J., M.D., 2060 Clarmar Way, San José 28,

Calif. (USA)

Fierz, H. K., Dr. med., Klinik und Untersuchungs-

zentrum für analytische Psychologie, Dolderstrasse 107,

8032 Zurich (Schweiz)

Finger, S., 40 Yeomalt Ave., Staten Island, N.Y. 10312

(USA)

Fleck, S., M.D., Yale University School of Medicine,

333 Cedar Street, New Haven, Conn. (USA)

Fordham, M., M.D., 1 St. Katharine's Precinct,

Regent's Park, London N.W.I (England)

Foulkes, S.H., M.D., 22 Upper Wimpole Street,

London W.1 (England)

Freud, A., M.D., 20 Maresfield Gardens, London

N.W.3 (England)

Gall wet, P.L.G., M.B., B.S., D.P.M., H.M. Prison,

Wormwood Scrubs, London W.12 (England)

Hoppe, K.D., M.D., The Hacker Clinic, 160 Lasky

Drive, Beverly Hills, Calif. (USA)

Hoxter, S., M.D., 44 Onslow Square, London S.W.7

(England)

Kayser, H., Dr., Psychiatrische Universitäts-Klinik

«Burghölzli», 8000 Zurich (Schweiz)

Knobel, M., M.D., Larrea $13812^{\circ}$ p, Buenos Aires

(Argentina)

Knobloch, F., Prof., M.D., Charles University

Policlinic, Karlova nam 32, Prague 1 (CSSR)

Laing, R.D., M.D., 21 Wimpole Street, London W.1

(England)

Langen, D., Prof. Dr., Universitäts-Nervenklinik,

74 Tubingen (Deutschland)

Laufer, M., 22 Bracknell Gardens, London N.W.3

(England)

Ledermann, E. K,, M.D., 97 Harley Street, London W.1

(England)

Lindem $\lambda$ nn, E., Prof., Ph. D., M.D., Department

of Psychiatry, Massachusetts General Hospital,

Fruit Street, Boston 14, Mass. (USA)

Main, T.F., M.D., The Cassel Hospital, Ham Common, 
Richmond, Surrey (England)

Marshall, M. A., R.N., M. S., 109 Comly Road, Lincoln Park, N.J. (USA)

Martin, D., S.R.N., S.C.M., M.T.D., The Cassel

Hospital, Ham Common, Richmond, Surrey (England)

Martinez, C, M.D., Av. Libertador Grl. S. Martin

1160 40B, Buenos Aires (Argentina)

McPherson, F.M., M.A., Department of Psychiatry,

University of Edinburgh, Professorial Unit, Jordanburn

Hospital, Edinburgh 10 (Scotland)

Menzies, I.E.P., M.A., The Tavistock Institute of

Human Relations, 3 Devonshire Street, London W.1

(England)

Mertens de Wilmars, Ch., Prof. Dr., Centre d'Etudes

psycho-médico-sociales, Université Catholique de

Louvain, Louvain (Belgique)

Molnar, J., M. S.W., Junipero Serra Boys' Club,

Los Angeles, Calif. (USA)

Newell, J. E., M. S.W., junipero Serra Boys' Club, Los Angeles, Calif. (USA)

Palazzoli Selvini, M., M.D., Viale Vittorio Veneto 12,

Milano (Italia)

Pavlovsky, E., M.D., Av. Libertador Grl. S. Martin

116040 B, Buenos Aires (Argentina)

Pasmore, J, M.R.C.S., L.R.C.P., 21 Edwards Square,

London W.8 (England)

Piers, G., M.D., 664 N. Michigan Ave.,

Chicago, Ill. (USA)

Piers, M.W., Ph. D., 664 N. Michigan Ave.,

Chicago, Ill (USA)

Rekola, J.K., M.D.,Lapinlahti Hospital, Helsinki (Finland;

Rojas Bermudez, J., M.D., Coronel Diaz 1564, 80 piso,

Dto 34, Buenos Aires (Argentina)

Ruesch, J., Prof., M.D., University of California

School of Medicine, San Francisco, Calif. 94122 (USA)

Satir, V.M., A.C.S.W., Family Project, Mental

Research Institute, 777 Bryant Street, Suite 3,

Palo Alto, Calif. (USA)

Schwartz, E.K., Ph.D., D. S. So, Postgraduate Center

for Mental Health, New York, N.Y. 10016 (USA)

Scott, R.D., M.D., Napsbury Hospital, Nr. St.Albans,

Herts (England)

Shlien, J.M., Ph.D., Department of Psychology,

University of Chicago, Chicago, Ill. 60637 (USA)

Sifneos, P.E., M.D., Department of Psychiatry,

Massachusetts General Hospital, Fruit Street, Boston 14, 
Mass. (USA)

Skynner, A.C.R., M.D., 60 Jacksons Lane, London N.6

(England)

Stanton, A.H., M.D., The McLean Hospital, Belmont,

Mass. 02178 (USA)

Stewen, A., M.D., Lapinlahti Hospital, Helsinki

(Finland)

Stock Whitaker, D., Ph. D., 27 Cromer Terrace,

Leeds 2 (England)

Sutherland, J.D., F.R.C.P.E., The Tavistock Clinic,

2 Beaumont Street, London W.1 (England)

Takala, K., M.D., Lapinlahti Hospital, Helsinki (Finland)

Tischler, S., M.A., D.P.M., 58a Wimpole Street,

London W.1 (England)

Trist, E.L., M.A., The Tavistock Institute of Human

Relations, 3 Devonshire Street, London W.1 (England)

Tuovtnen, M., M.D., Lapinlahti Hospital, Helsinki

(Finland)

Ucha Udabe, R., M.D., Rivadavia $18238^{\circ} \mathrm{p}$ B,

Buenos Aires (Argentina)

Walton, H. J., M.D., D.P.M., Department of

Psychiatry, University of Edinburgh, Professorial Unit,

Jordanburn Hospital, Edinburgh 10 (Scotland)

Weddell, D, S.R.N., C.M.B., The Garden Flat,

30 Frognal Lane, London N.W.3 (England)

Weinberg, L., B.A., M.A., 69 Knoll Terrace, West

Caldwell, N.J. (USA)

Zeise, W. J., Obermedizinalrat Dr., Ätztlich-psycho-

logische Zentralstelle für Erziehu gsberatung,

Stadtjugendamt, Goethestrasse 53, 8000 München 15

(Deutschland)

Zetzel, E.R., M.D., 14 Hubbard Park, Cambridge,

Mass. (USA)

Ziferstein, I., M.D., 1819 North Curson Ave.,

Los Angeles, Calif. 90046 (USA)

Zuк, G.H., M.D., Eastern Pennsylvania Psychiatric

Institute, Henry Ave, and Abbotsford Rd.,

Philadelphia 29, Pa. (USA)

Introduction

The theme chosen for this Congress was "New Developments in Psychotherapy". Each day the

Plenary Sessions covered a different topic-Childhood, Adulthood, Small and, finally, Large

Group Processes. In this way we demonstrated how psychotherapists now are involved in the research on and treatment of mental processes from the infant's birth to his full adult involvement in society. This recognition that the psychotherapist has a viewpoint as participant observer in the whole range of human activities, characterises the most significant development of the past 25 years. Much of the impetus of this development arose from the experiences of 
wartime, where psychiatrists were called on for the first time to help in the understanding and modification of behaviour in large masses of people, military and civil alike. Here the psychiatrist enlarged his experience and his understanding and had to fashion new conceptual tools for this task. Here he became a part of a team and began a collaboration that has characterised so much of the useful extension of knowledge and practice of the past 25 years. He had to integrate, his own findings with those of his collaborators, psychologists and social scientists, and nowadays the list must be extended to include ethology, anthropology, biology and epidemiology to name but a few. This is the process that Hartmann has named the "useful penetration" of one discipline by another. Here also began the intensive study of inter-personal relationships that follows the intensive study of intra-psychic processes that characterised the past 50 years under the leadership of psycho-analysis. The significant task of the next 25 years is to accelerate the inter-penetration of those two studies -intrapsychic and interpersonal and to produce a fruitful synthesis from what is still a dialectic.

It is this thinking that influenced the Editors choice of papers for the printed proceedings. Studies of Adolescence and of Family Psychiatry force us to face the task of integrating the intrapsychic and interpersonal frames of reference and at the same time focus on two of the most important and fast growing areas of psychiatric research and practice.

$\mathrm{X}$

Introduction

1 hope that our friends and colleagues whose papers have had to be omitted from the printed proceedings will recognise the cogency of this argument and will feel that even in the absence of their papers they have contributed to the Gestalt of the proceedings.

The printed proceedings has to become a permanent record and useful synthesis of this wide ranging Congress. We hope that the Congress itself will be remembered as an enjoyable and fruitful experience for all who took part.

Richmond, Surrey, 1965

Malcolm Pines

Presidential Address at the Opening Session

$\Lambda$ s president of the International Federation for Medical Psychotherapy it is my privilege and pleasure to welcome you here in London. I want to extend my greetings to the delegates of our member societies, the individual members who came from countries where no national society of psychotherapists has as yet been established, and last but not least, also to the guest participants. This is our Sixth International Congress, because we are well justified to number our International Congresses from that first Post-War Conference which was held right here in London in 1948. It had been initiated by our English Colleague Dr. Crichton Miller and was presided over by another British doctor, by Dr. J.R. Rees. It was at this Conference in London 16 years ago that the idea of a new International Federation for Medical Psychotherapy was born, after the former International Organization had been killed by World War II. It is obvious from this historical review that the idea as well as its materialization are mainly of British origin. We owe it, then, to a great extent to this country that we exist at all in the form in which we have come together to-day.

Geographically speaking, we have completed a vast circle since, with our return to London after having met in Leyden, Zurich, Barcelona and Vienna. But I am convinced that we have not been going in circles, as far as our scientific work is concerned. On the contrary, I believe that we 
have forged ahead. This moving ahead is particularly well expressed by the principal theme of this Congress. Nothing could be oriented more towards the future than its title:

"New Development in Psychotherapy"

Another pleasant duty is to express the most sincere gratitude of the board of the IFMP to the Royal Medico-Psychological Association for sponsoring this Congress. I would like to mention especially that I had the opportunity to watch closely the enormous amount of work which the local organizing committee had to carry out. I cannot help

XII

Presidential Address at the Opening Session

but admire the conscientiousness, care, and enthusiasm with which all members of this

committee carried out their task over the past three years.

I am sure that I may speak for each and every one of us in expressing thanks to our F,nglish

Colleagues.

Finally, it is my pleasure to hand over the chair of this Congress to the president of the Royal Medico-Psychological Association, Dr. Ian Skottowf.

Prof. Dr. M. Boss

President of the International Federation for Medical Psychotherapy 